\title{
Comorbidities according to airflow limitation severity: data from comprehensive health examination in Japan
}

\author{
Shota Masuda ${ }^{1}$, Hisamitsu Omori ${ }^{1,2^{*}}$, Ayumi Onoue ${ }^{2}$, Xi Lu$^{1}$, Kenichi Kubota ${ }^{3}$, Noritaka Higashi ${ }^{3}$, \\ Yasuhiro Ogata ${ }^{3}$ and Takahiko Katoh ${ }^{1}$
}

\begin{abstract}
Objectives: The present study aimed to investigate the relationship between airflow limitation (AL) severity and comorbidities in comprehensive health examination.

Methods: This cross-sectional study included 6661 men and 6044 women aged 40-89 who underwent a lung function test during medical checkups. AL was defined as forced expiratory volume in $1 \mathrm{~s} /$ forced vital capacity of $<0.7$. Logistic regression analysis was used to assess the association between AL severity and the presence of comorbidities.

Results: When compared with the normal lung function group, subjects with AL had a higher prevalence of lung cancer (odd ratio (OR) 9.88, 95\% confidence interval (Cl) 3.88-25.14) in men, hypertension (OR 1.63,95\% Cl 1.26-2.10) in women, diabetes and hyperglycemia (OR 1.23, 95\% Cl 1.02-1.49 in men, OR 1.61, 95\% Cl 1.18-2.20 in women) in men and women after adjusting for potential confounders. In men, lung cancer and MetS (the Joint Interim Statement: JIS) were significantly associated with moderate-to-very severe AL after adjustment. In women, hypertension, diabetes and hyperglycemia, MetS (JIS), and MetS (the Japanese Committee of the Criteria for MetS: JCCMS) were significantly associated with mild AL after adjustment. Hypertension was significantly associated with moderate-to-very severe AL after adjustment in women.
\end{abstract}

Conclusions: Significant relationships were found between AL severity and the presence of comorbid lung cancer in men, hypertension in women, diabetes and hyperglycemia, and MetS in men and women. Knowledge of comorbidities associated with AL should be widely publicized to raise the awareness of chronic obstructive pulmonary disease (COPD).

Keywords: COPD, Comorbidity, Airflow limitation, Lung function, Health checkup

\section{Introduction}

Chronic obstructive pulmonary disease (COPD), a common preventable and treatable disease, is characterized by persistent airflow limitation that is usually progressive and associated with an enhanced chronic inflammatory response in the airways and the lung to noxious particles or gases [1,2]. Exacerbations and comorbidities contribute to the overall severity in individual patients $[1,2]$.

\footnotetext{
*Correspondence: omorih@gpo.kumamoto-u.ac.jp

'Department of Public Health, Faculty of Life Sciences, Kumamoto University, 1-1-1 Honjou, Chuo-ku, Kumamoto 860-8556, Japan

${ }^{2}$ Department of Biomedical Laboratory Sciences, Faculty of Life Sciences, Kumamoto University, 4-24-1 Kuhonji, Chuo-ku, Kumamoto 862-0976, Japan Full list of author information is available at the end of the article
}

COPD is a leading cause of morbidity and mortality worldwide and results in an economic and social burden that is both substantial and increasing $[1,2]$. The World Health Organization (WHO) reported that COPD is the 3rd leading cause of death in the world and is presently the 5th leading cause of death among high-income countries, with a rate of 31 deaths per 10,000 people [3]. Furthermore, the burden of COPD is still expected to continue increasing [3].

COPD frequently coexists with other conditions often known as comorbidities that may have a significant impact on prognosis [1, 2]. Most common comorbidities are cardiovascular disease, hypertension, metabolic syndrome 
and diabetes, osteoporosis, musculoskeletal disease, lung cancer, and anxiety and depression [2]. These comorbidities have a significant impact on health status, health care, hospital admission and eventually death in patients with COPD [1, 2, 4-7]. The prevalence of individual comorbidities varies widely between different studies.

There are limited data available regarding the severity of airflow limitation (AL) and comorbidities, especially among subjects undergoing medical health checkups, in Japan. Therefore, the aim of the present study was to determine the relationship between AL and the common, chronic comorbid conditions of cardiovascular disease, hypertension, metabolic syndrome and diabetes, osteoporosis, lung cancer, and anxiety and depression.

\section{Materials and methods}

\section{Subjects}

Figure 1 shows the flow chart for selecting the subjects with either AL or a normal lung function. A total of 25,879 people visited the Japanese Red Cross Kumamoto Health Care Center for medical health checkups between April 2009 and March 2010. Of these, 16,901 subjects aged 40-89 years underwent comprehensive health examination that included spirometry, as previously described [8].

The comprehensive health examination included interview questionnaires, a physical examination, blood sampling, and spirometry, as previously described $[8,9]$. The interview questionnaires were conducted by a trained public health nurse to obtain data regarding medical history including the use of medications, and smoking status.
The never smokers consisted of those who denied any past or current smoking. The former smokers were those who reported smoking cessation prior to the examination. The current smokers were those who reported smoking at least one cigarette a day. Pack-years were calculated by multiplying the number of years of smoking by the average number of cigarettes smoked per day and dividing it by 20 . All the participants were evaluated by a physician.

The subjects with asthma (number $(\mathrm{n})=597)$, tuberculosis and pleurisy $(n=300)$, bronchiectasis $(n=28)$, pneumothorax $(n=57)$, bronchitis $(n=171)$, and other respiratory diseases $(n=288)$ were excluded. In the present study, the subjects with lung cancer were included because lung cancer is an important comorbidity and a leading cause of death in COPD patients [1]. None of the subjects were diagnosed with COPD with acute exacerbation. The subjects with $\mathrm{FEV}_{1 /} \mathrm{FVC}>70 \%$ and $\% \mathrm{FEV}_{1}<$ $80 \%(n=2,755)$ were also excluded from this study. Data from a total of 12,705 subjects (6661 men and 6044 women) were including in the final analyses (Fig. 1, Table 1). None of the subjects had a history of exposure to workplace dust. Subjects were divided by lung function (11,785 subjects (6010 men and 5775 women)) had normal lung function, 469 subjects (257 men and 212 women) had mild AL, and 451 subjects ( 394 men and 57 women) had moderate-to-very severe AL) (Table 1).

All study subjects gave their informed consent to undergo a screening examination. Our research protocol was approved by the Human Ethics Committee of

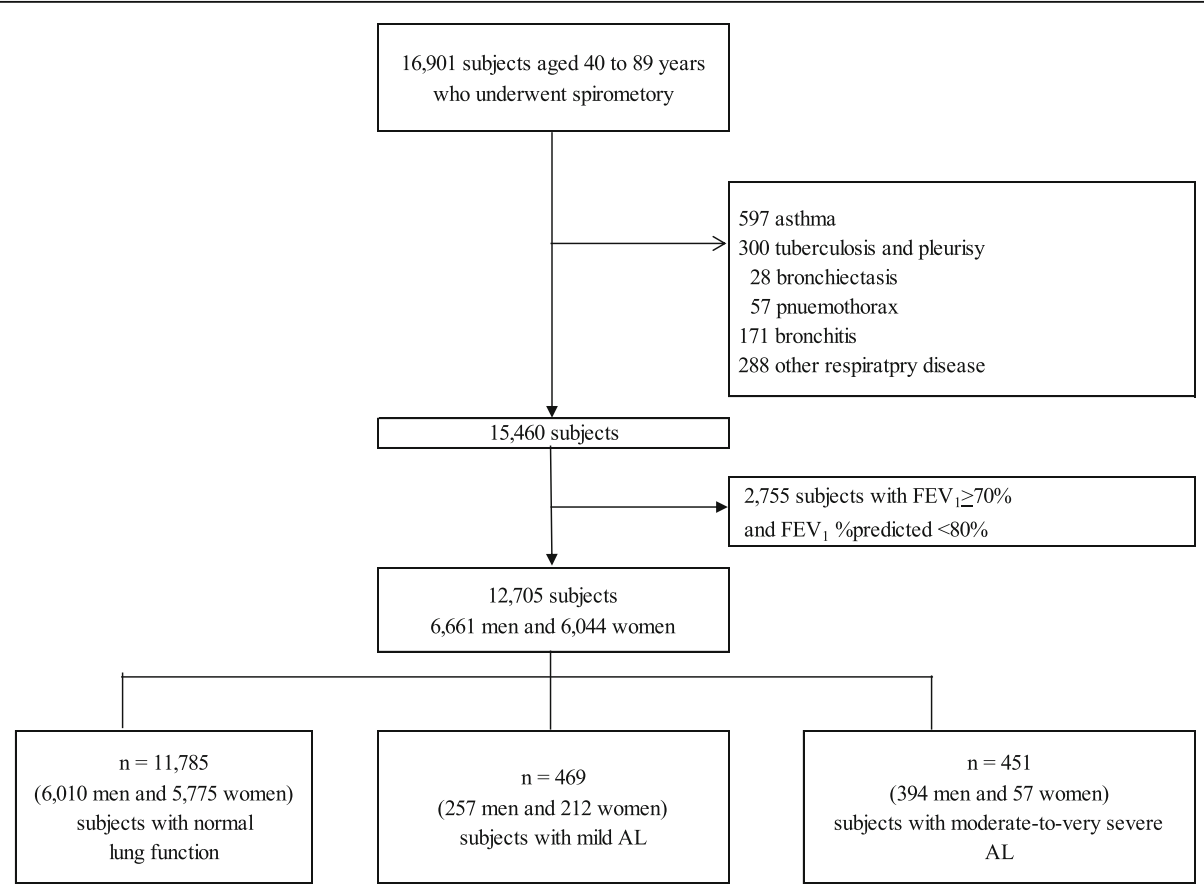

Fig. 1 Flow chart for selecting the subjects with AL or normal lung function. AL airflow limitation, $F E V_{1}$ forced expiratory volume in $1 \mathrm{~s}$ 
Table 1 The characteristics of the study subjects based on lung function

\begin{tabular}{|c|c|c|c|c|c|c|c|c|}
\hline \multirow[t]{3}{*}{ Total $(n=12,705)$} & \multirow{2}{*}{\multicolumn{2}{|c|}{$\begin{array}{l}\text { Normal } \\
(n=11,785)\end{array}$}} & \multicolumn{4}{|l|}{$\mathrm{AL}$} & \multirow{2}{*}{\multicolumn{2}{|c|}{$p$ Value }} \\
\hline & & & \multicolumn{2}{|l|}{$\begin{array}{l}\text { Mild } \\
(n=469)\end{array}$} & \multicolumn{2}{|c|}{$\begin{array}{l}\text { Moderate-to-very severe } \\
(n=451)\end{array}$} & & \\
\hline & $\begin{array}{l}\text { Men } \\
(n=6,010)\end{array}$ & $\begin{array}{l}\text { Women } \\
(n=5,775)\end{array}$ & $\begin{array}{l}\text { Men } \\
(n=257)\end{array}$ & $\begin{array}{l}\text { Women } \\
(212)\end{array}$ & $\begin{array}{l}\text { Men } \\
(n=394)\end{array}$ & $\begin{array}{l}\text { Women } \\
(n=57)\end{array}$ & Men & Women \\
\hline$\overline{\text { Age, yr }}$ & $56.4(9.8)$ & $55.1(9.6)$ & $63.0(10.5)^{* *}$ & $57.4(10.6)^{* *}$ & $59.7(11.0)^{* * \# \#}$ & $55.4(12.1)$ & $<0.001$ & 0.002 \\
\hline Height, $\mathrm{cm}$ & $167.7(6.2)$ & $155.6(5.7)$ & $166.2(6.5)^{* *}$ & $155.6(5.4)$ & $167.8(6.4)^{\# \#}$ & $156.3(7.0)$ & $<0.001$ & 0.626 \\
\hline Weight, kg & $66.9(9.7)$ & $53.6(8.4)$ & $64.5(8.8)^{* *}$ & $54.2(8.3)$ & $66.3(9.8)$ & $52.7(7.9)$ & $<0.001$ & 0.457 \\
\hline Abdominal circumference, $\mathrm{cm}$ & $85.4(7.8)$ & $81.0(8.9)$ & $84.4(6.9)$ & $82.7(7.8)^{*}$ & $85.7(8.2)$ & $80.5(8.4)$ & 0.122 & 0.023 \\
\hline $\mathrm{BMI}, \mathrm{kg} / \mathrm{m}^{2}$ & $23.7(2.9)$ & $22.1(3.3)$ & $23.3(2.7)$ & $22.4(3.0)$ & $23.5(3.0)$ & $21.6(2.8)$ & 0.03 & 0.243 \\
\hline Systolic blood pressure, $\mathrm{mmHg}$ & $121.1(16.8)$ & $118.3(17.8)$ & $123.2(18.9)$ & $123.6(18.4)^{* *}$ & $125.8(18.3)^{* *}$ & $125.9(18.0)^{*}$ & $<0.001$ & $<0.001$ \\
\hline Diastolic blood pressure, $\mathrm{mmHg}$ & $76.2(11.9)$ & $72.8(11.9)$ & $75.1(11.6)$ & $75.4(12.7)^{*}$ & $(74.8(12.1)$ & $72.0(10.3)$ & 0.032 & 0.006 \\
\hline \multicolumn{9}{|l|}{ Smoking status, n (\%) } \\
\hline Never smokers & $1,995(33.2)$ & $5,216(90.3)$ & $71(27.6)$ & $192(90.6)$ & $(81(20.5)$ & $51(89.5)$ & & \\
\hline Former smokers & $2,298(38.2)$ & $257(4.5)$ & $(116(45.1)$ & $9(4.2)$ & (165 (41.9) & $4(7.0)$ & & \\
\hline Current smokers & $1,717(28.6)$ & $302(5.2)$ & $(70(27.3)$ & $11(5.2)$ & $148(37.6)$ & $2(3.5)$ & $<0.001$ & 0.881 \\
\hline Pack-years & $18.3(20.1)$ & $1.2(4.7)$ & $24.4(24.4)^{* *}$ & $1.9(7.6)$ & $28.6(25.9)^{* * \#}$ & $1.3(4.2)$ & $<0.001$ & 0.081 \\
\hline \multicolumn{9}{|l|}{ Lung function } \\
\hline $\mathrm{FVC}, \mathrm{mL}$ & $\begin{array}{l}4,029.0 \\
(642.6)\end{array}$ & $\begin{array}{l}3,280.0 \\
(776.8)\end{array}$ & $\begin{array}{l}4,227.6 \\
(645.7)^{* *}\end{array}$ & $\begin{array}{l}3,490.5 \\
(787.2)^{* *}\end{array}$ & $\begin{array}{l}3,242.4 \\
(618.9)^{* * \# \#}\end{array}$ & $\begin{array}{l}2,306.0 \\
(468.6)^{* * \# \#}\end{array}$ & $<0.001$ & $<0.001$ \\
\hline $\mathrm{FEV}_{1}, \mathrm{~mL}$ & $\begin{array}{l}3,226.1 \\
(519.0)\end{array}$ & $\begin{array}{l}2,645.3 \\
(628.8)\end{array}$ & $\begin{array}{l}2,789.2 \\
(445.5)^{* *}\end{array}$ & $\begin{array}{l}2,275.7 \\
(506.7)^{* *}\end{array}$ & $\begin{array}{l}2,023.2 \\
(444.8)^{* * \# \#}\end{array}$ & $\begin{array}{l}1,427.0 \\
(308.2)^{* * \# \#}\end{array}$ & $<0.001$ & $<0.001$ \\
\hline $\mathrm{FEV}_{1} / \mathrm{FVC}, \%$ & $80.2(5.2)$ & $80.8(5.3)$ & $66.0(3.3)^{* *}$ & $65.4(3.8)^{* *}$ & $62.3(6.8)^{* * \# \#}$ & $62.0(6.7)^{* * \# \#}$ & $<0.001$ & $<0.001$ \\
\hline $\mathrm{FEV}_{1} \%$ predicted, $\%$ & $98.8(14.0)$ & $120.8(29.2)$ & $92.3(11.7)^{* *}$ & $105.7(19.9)$ & $\begin{array}{l}63.8 \\
(00312.4)^{* * \# \#}\end{array}$ & $65.1(12.1)^{* * \# \#}$ & $<0.001$ & $<0.001$ \\
\hline \multicolumn{9}{|l|}{ Laboratory data } \\
\hline Fasting glucose, mg/dL & $102.2(19.5)$ & $97.9(17.5)$ & $104.2(19.2)$ & $100.1(18.7)$ & $104.2(22.3)$ & $97.3(15.3)$ & 0.053 & 0.03 \\
\hline $\begin{array}{l}\text { Triglycerides, } \mathrm{mg} / \mathrm{dL} \\
\text { (interquartile range) }\end{array}$ & $\begin{array}{l}106.0(74- \\
157.0)\end{array}$ & $\begin{array}{l}86.0(63.0- \\
127.0)\end{array}$ & $\begin{array}{l}109.0(82.5- \\
162.5)\end{array}$ & $\begin{array}{l}102.0(71.0- \\
141.8)\end{array}$ & $\begin{array}{l}102.0(75.0- \\
147.0)\end{array}$ & $\begin{array}{l}91.0(68.5- \\
115.5)\end{array}$ & 0.222 & 0.001 \\
\hline HDL cholesterol, mg/dL & $61.7(16.3)$ & $68.7(17.0)$ & $61.6(19.9)$ & $66.9(16.8)$ & $61.5(15.6)$ & $73.2(19.7)^{\#}$ & 0.961 & 0.04 \\
\hline LDL cholesterol, mg/dL & $119.3(28.7)$ & $119.2(28.9)$ & $116.8(28.2)$ & $119.6(28.5)$ & $116.7(28.0)$ & $111.7(27.6)$ & 0.09 & 0.15 \\
\hline White blood cell count,/ $\mu \mathrm{L}$ & $\begin{array}{l}5,573.0 \\
(1538.1)\end{array}$ & $\begin{array}{l}5,227.3 \\
(1454.6)\end{array}$ & $\begin{array}{l}5,946.7 \\
(1744.1)^{*}\end{array}$ & $\begin{array}{l}5,638.2 \\
(1661.7)^{* *}\end{array}$ & $\begin{array}{l}5,842.9 \\
(1576.5)^{*}\end{array}$ & $\begin{array}{l}5,157.9 \\
(1235.5)\end{array}$ & $<0.001$ & $<0.001$ \\
\hline
\end{tabular}

Data are expressed as means (standard deviation), median (interquartile range), or as number (n) (percentage)

Airflow limitation $(\mathrm{AL})$ was difined as $\mathrm{FEV}_{1} / \mathrm{FVC}<0.7$

Pack years $=($ number of cigareetes smoked per day $\times$ number of year smoked $) / 20$

$B M I$ body mass index, FVC forced vital capacity, $F E V_{1}$ forced expiratory volume in one second, $H D L$ high-density lipoprotein, $L D L$ low-density lipoprotein, $h s C R P$

hypersensitivity $C$-reactive protein

${ }^{*} p<0.05$ compared with normal lung function

${ }^{\#} p<0.05$ compared with mild airflow limitation

Kumamoto University (Numbers 84 ) and the Japanese Red Cross Kumamoto Health Care Center.

\section{Lung function tests}

Spirometry was performed with an electronic spirometer (DISCOM-21 FX: CHEST MI, Tokyo, Japan) as previously described [8-13], using equipment and quality criteria that complied with international recommendations [14]. Reversibility tests were not performed for this study, and the classifications were based on pre-bronchodilator levels. According to Global Initiative for Chronic Obstructive
Pulmonary Disease (GOLD) guidelines, we defined AL as an $\mathrm{FEV}_{1} / \mathrm{FVC}$ ratio of $<70 \%$ [1]. The predicted values were determined from the prediction equations published by the Japanese Respiratory Society (JRS) [15]: men, $0.036 \times$ height (cm)-0.028 $\times$ age-1.178; women, $0.022 \times$ height $(\mathrm{cm})-0.022$ $\times$ age- 0.005 . The criteria used for the AL staging were also developed according to GOLD guidelines, as follows: Stage I (mild $\mathrm{AL}$ ): $\mathrm{FEV}_{1} / \mathrm{FVC}<70 \%$ and $\% \mathrm{FEV}_{1}>80 \%$; Stage II (moderate $\mathrm{AL}$ ): $\mathrm{FEV}_{1} / \mathrm{FVC}<70 \%$ and $50 \%<\% \mathrm{FEV}_{1}<80 \%$; Stage III (severe AL): $\mathrm{FEV}_{1} / \mathrm{FVC}<70 \%$ and $30 \%<\% \mathrm{FEV}_{1}<$ $50 \%$; and Stage IV (very severe $\mathrm{AL}$ ): $\mathrm{FEV}_{1} / \mathrm{FVC}<70 \%$ and 
$\% \mathrm{FEV}_{1}<30 \%$. The subjects were divided into three groups: a control group (normal lung function), GOLD Stage I (mild AL), and GOLD Stages II-IV (moderate-to-very severe $\mathrm{AL}$ ). The subjects with normal lung function were defined as having a $\mathrm{FEV}_{1} / \mathrm{FVC}>70 \%$ and $\% \mathrm{FEV}_{1}>80 \%$.

\section{Laboratory measurements}

Following an overnight fast, blood samples were obtained to measure the serum levels of routine medical checkup indicators, including triglycerides, high-density lipoprotein cholesterol (HDL-C), low-density lipoprotein cholesterol (LDL-C), fasting glucose, and white blood cell count, as previously described [8].

\section{Comorbidities}

The following comorbidities were evaluated according to the severity of AL in this study: lung cancer, hypertension, diabetes mellitus and hyperglycemia, dyslipidemia, metabolic syndrome, ischemic heart disease, osteoporosis, and depression and mental disease.

We ascertained the presence of lung cancer, ischemic heart disease, osteoporosis, and depression and mental disease by means of an interview. The presence of each comorbidity was confirmed by a physician. We defined hypertension as antihypertensive medication use, a systolic blood pressure of $130 \mathrm{mmHg}$ or more, or a diastolic blood pressure of $85 \mathrm{mmHg}$ or more. Dyslipidemia was defined as medication use, a triglyceride level of $150 \mathrm{mg} / \mathrm{dL}$ or more, an LDL cholesterol level of $140 \mathrm{mg} / \mathrm{dL}$ or more, or an HDL cholesterol level of less than $40 \mathrm{mg} / \mathrm{dL}$, as described previously [8]. Diabetes and hyperglycemia were defined as medication use or a fasting glucose level of $110 \mathrm{mg} / \mathrm{dL}$ or more. We defined the presence of metabolic syndrome (MetS) using the following two criteria: the Joint Interim Statement (JIS) [16] and the Japanese Committee of the Criteria for MetS (JCCMS) [17]. MetS was diagnosed according to the JIS [16] when three or more of following components were present: 1 ) central obesity (waist circumference $\geq 90 \mathrm{~cm}$ in men and $\geq 80 \mathrm{~cm}$ in women); 2) high blood pressure (systolic blood pressure $\geq 130 \mathrm{mmHg}$ and/ or diastolic blood pressure $\geq 85 \mathrm{mmHg}$ and/or current use of medication for hypertension); 3) high triglyceride (triglyceride $>150 \mathrm{mg} / \mathrm{dL}$ and/or current use of medication for triglyceride); 4) low HDL cholesterol (HDL cholesterol < $40 \mathrm{mg} / \mathrm{dL}$ in men or $<50 \mathrm{mg} / \mathrm{dL}$ in women and/or current use of medication for HDL cholesterol); and 5) impaired fasting glucose (fasting glucose $\geq 100 \mathrm{mg} / \mathrm{dL}$ and/or current use of medication for diabetes mellitus).

Furthermore, we diagnosed metabolic syndrome according to Japanese diagnostic criteria [17]: a waist circumference of at least $85 \mathrm{~cm}$ for men and $90 \mathrm{~cm}$ for women, and 2 or more of the following components: 1) a triglyceride level of $150 \mathrm{mg} / \mathrm{dL}$ and/or current use of medication for triglyceride or more and/or an HDL cholesterol level of less than $40 \mathrm{mg} / \mathrm{dL}$ and/or current use of medication for HDL cholesterol; 2) a systolic blood pressure of $130 \mathrm{mmHg}$ or more and/or a diastolic blood pressure of $85 \mathrm{mmHg}$ or more and/or current use of medication for hypertension; and 3) a fasting glucose of $110 \mathrm{mg} / \mathrm{dL}$ or more and/or current use of medication for diabetes mellitus.

\section{Statistical analyses}

Data were presented as number of cases, mean (standard deviation), or median with interquartile range. Differences among normal lung function, mild AL, and moderate-tovery severe AL were compared using a one-way analysis of variance or Kruskal-Wallis test in case of not normally distributed data followed by Scheffe's post-hoc tests for continuous variables and a chi-squared test for categorical variables. A multivariate logistic regression model adjusted for age, BMI, and smoking was used to assess the relationship between severity of AL and comorbidities, with "normal lung function" as the reference. All statistical analyses were performed with IBM SPSS Statistics 22.0 software. Whether the data showed normal distribution was assessed by Shapiro-Wilk test. Values of $p<0.05$ were considered to be statistically significant. There are no missing data in the present study.

\section{Results}

\section{Study population characteristics}

Table 1 shows the characteristics of the study subjects based on their lung function status. The prevalence of AL in this study population for the GOLD stages "mild" and "moderate-to-very severe" $\mathrm{AL}$ were $3.7 \%(n=469)$ and $3.5 \%(n=$ 451 ), respectively. Overall prevalence of $\mathrm{AL}$ was $7.2 \%$. In men, 3.9\% $(n=257)$ had mild airflow limitation and 5.9\% ( $n$ $=394$ ) had moderate-to-very severe airflow limitation. In women, 3.5\% $(n=212)$ had mild airflow limitation and 1.0\% $(n=57)$ had moderate-to-very severe airflow limitation. Among 394 men with moderate-to-very severe AL, most of the subjects were at moderate $(n=343,5.15 \%)$ compared to severe $(n=45,0.68 \%)$ and very severe $(n=6,0.09 \%)$. In 57 women with moderate-to-very severe AL, prevalence of the subjects with moderate, severe and very severe AL were $0.83 \%(n=50), 0.12 \%(n=7)$, and $0 \%(n=0)$, respectively.

In this study, $6.6 \%(n=31)$ of subjects with mild AL and $1.6 \%(n=7)$ of subjects with moderate-to-very severe AL had been diagnosed with COPD/emphysema. Remaining had not been diagnosed with COPD/emphysema.

Significant differences in the lung function status were found with regard to age in men and women, height, weight, smoking status, pack-years in men, abdominal circumference, fasting glucose, triglyceride, and HDLcholesterol in women. White blood cell count was significantly higher in the subjects with mild and moderate-to-very severe AL than in those with normal lung function in men. 


\section{Comorbidities}

Table 2 shows the prevalence of comorbidities between subjects with mild AL, moderate-to-very severe AL, and normal lung function. Hypertension was the most prevalent comorbidity in men and women in the subjects with AL. The present study shows a low ratio of ischemic heart disease, osteoporosis, and depression and mental disease. When compared with the normal lung function group, subjects in AL group had a significantly higher prevalence of lung cancer and diabetes and hyperglycemia in men and lung cancer, hypertension, diabetes and hyperglycemia and osteoporosis in women. No significant difference were found in dyslipidemia, Mets (JIS), Mets (JCCMS), ischemic heart disease, osteoporosis, and depression and mental disease in the different groups of AL severity.

Table 3 displays the relationship between $\mathrm{AL}$ and comorbidities according to lung function. In logistic regression models adjusting for sex, age, BMI, and smoking status, the risks of lung cancer (odd ratio (OR): 9.88; 95\% confidence interval (CI): 3.88-25.14), and diabetes and hyperglycemia (OR: 1.23; 95\% CI: 1.02-1.49) were higher in subjects with AL compared to those with normal lung function and in logistic regression models adjusting for age and smoking status, the risk of MetS (JIS) (OR: 1.32; 95\% CI: 1.02-1.69) was higher in subjects with moderate-to-very severe airflow limitation in men. However, hypertension, dyslipidemia, MetS (JCCMS) and ischemic heart diseases were not significantly associated with AL in men in the present study.

In women, the risks of hypertension were significantly higher in subjects with AL (OR: 1.63; 95\% CI: 1.262.10), mild AL (OR: 1.59; 95\% CI: 1.20-2.11), and moderate-to-very severe AL (OR: 1.79; 95\% CI: 1.043.10) compared to those with normal lung function after adjusting for age, BMI, smoking status. The risks of diabetes and hyperglycemia were significantly higher in subjects with AL (OR: 1.61; 95\% CI: 1.18-2.20) and mild AL (OR: 1.68; 95\% CI: 1.19-2.37) compared to those with normal lung function after adjusting for age, BMI, smoking status. The risks of MetS (JIS) (OR: 1.43; 95\% CI: 1.04-1.98) and MetS (JCCMS) (OR: 1.83; 95\% CI:

Table 2 Prevalence of comorbidites between subjects with mild AL, moderate-to-severe AL, and normal lung function

\begin{tabular}{|c|c|c|c|c|}
\hline \multirow[t]{2}{*}{ Comorbidity } & \multirow{2}{*}{$\begin{array}{l}\text { Normal } \\
n=11,785\end{array}$} & \multicolumn{2}{|l|}{$\mathrm{AL}$} & \multirow[t]{2}{*}{$p$ value } \\
\hline & & $\begin{array}{l}\text { Mild } \\
n=469\end{array}$ & $\begin{array}{l}\text { Moderate-to-very severe } \\
n=451\end{array}$ & \\
\hline Men $(n=6,661)$ & $n=6,010$ & $n=257$ & $n=394$ & \\
\hline Lumg cancer & $9(0.15)$ & $3(1.17)$ & $7(1.78)$ & $<0.001$ \\
\hline Hypertension & $2,602(43.29)$ & $127(49.42)$ & $210(53.30)$ & 0.064 \\
\hline Diabetes and hyperglycemia & $1,241(20.65)$ & $65(25.29)$ & $102(22.62)$ & 0.012 \\
\hline Dyslipidemia & $2,887(48.04)$ & $118(45.91)$ & $182(46.19)$ & 0.637 \\
\hline MetS (JIS) & $1,009(16.79)$ & $44(17.12)$ & $84(21.32)$ & 0.068 \\
\hline MetS (JCCMS) & $964(16.04)$ & $46(18.11)$ & $68(17.26)$ & 0.611 \\
\hline Ischemic heart disease & $164(2.73)$ & $7(2.72)$ & $14(3.55)$ & 0.627 \\
\hline Osteoporosis & $8(0.13)$ & $0(0)$ & $1(0.25)$ & 0.684 \\
\hline Depression and mental disease & $17(0.28)$ & $0(0)$ & $1(0.25)$ & 0.692 \\
\hline Women $(n=6,044)$ & $n=5,775$ & $n=212$ & $n=57$ & \\
\hline Lumg cancer & $15(0.26)$ & $2(0.94)$ & $1(1.75)$ & 0.026 \\
\hline Hypertension & $1,886(32.66)$ & $97(45.75)$ & $25(43.86)$ & $<0.001$ \\
\hline Diabetes and hyperglycemia & $754(13.06)$ & $44(20.75)$ & $9(15.79)$ & 0.005 \\
\hline Dyslipidemia & $2,433(42.13)$ & $94(44.34)$ & $17(29.82)$ & 0.138 \\
\hline MetS (JIS) & $1,024(17.73)$ & $51(24.06)$ & 9 (15.79) & 0.057 \\
\hline MetS (JCCMS) & $200(3.46)$ & $14(6.60)$ & $2(3.51)$ & 0.054 \\
\hline Ischemic heart disease & $61(1.06)$ & $3(1.42)$ & $0(0)$ & 0.648 \\
\hline Osteoporosis & $316(5.47)$ & 19 (8.96) & $6(10.53)$ & 0.027 \\
\hline Depression and mental disease & $15(0.26)$ & $1(0.47)$ & $0(0)$ & 0.779 \\
\hline
\end{tabular}

Data presented are number (percent)

Ischemic heart disease; including angina pectoris and myocardial infarction Airflow limitation (AL) was dfined as $\mathrm{FEV} / \mathrm{FVC}_{1}<0.7$

Hypertension; antihypertensive medication use or systolic blood pressure $\geqq 130 \mathrm{mmHg}$ or diastolc blood pressure $\geqq 85 \mathrm{mmHg}$ Diabetes and hypergfycemia; blood glucose-lowerning medication use or elevated fasting glucose $\geqq 110$ Dyslipidemia; medication use or triglycerides $\geqq 150 \mathrm{mg} / \mathrm{dl}, \mathrm{HDL}-\mathrm{C}<40 \mathrm{mg} / \mathrm{dl}$ or $\mathrm{LDL}-\mathrm{C}$ $\geqq 140 \mathrm{mg} / \mathrm{dl}$

AL airflow limitation, MetS metabolic syndrome, JIS Joint Interim Statement, JCCMS Japanese Committee of Criteria for MetS 
Table 3 Relationship between AL and comorbidities according to lung function

\begin{tabular}{|c|c|c|c|c|c|c|c|}
\hline \multirow[t]{2}{*}{ Comorbidity } & \multirow{2}{*}{$\begin{array}{l}\text { Normal } \\
n=11,785\end{array}$} & \multirow{2}{*}{$\begin{array}{l}\text { AL total } \\
n=920\end{array}$} & \multirow[t]{2}{*}{$p$ Value } & \multicolumn{4}{|l|}{$\mathrm{AL}$} \\
\hline & & & & $\begin{array}{l}\text { Mild } \\
n=469\end{array}$ & $p$ Value & $\begin{array}{l}\text { Moderate-to-very } \\
\text { severe } n=451\end{array}$ & $p$ Value \\
\hline Men $(n=6,661)$ & $n=6,010$ & $n=651$ & & $n=257$ & & $n=394$ & \\
\hline \multicolumn{8}{|l|}{ Lung cancer } \\
\hline Crude OR (95\% Cl) & 1.00 & $10.40(4.21-25.69)$ & $<0.001$ & $7.88(2.12-29.27)$ & 0.002 & $12.06(4.47-32.56)$ & $<0.001$ \\
\hline Adjusted OR (95\% Cl) & 1.00 & $9.88(3.88-25.14)$ & $<0.001$ & $6.52(1.70-24.99)$ & 0.006 & $12.58(4.53-34.94)$ & $<0.001$ \\
\hline \multicolumn{8}{|l|}{ Hypertension } \\
\hline Crude OR (95\% Cl) & 1.00 & $1.21(1.03-1.42)$ & 0.024 & $1.28(1.00-1.64)$ & 0.053 & $1.16(0.95-1.42)$ & 0.156 \\
\hline Adjusted OR (95\% Cl) & 1.00 & $1.08(0.91-1.27)$ & 0.404 & $1.08(0.83-1.39)$ & 0.585 & $1.08(0.87-1.33)$ & 0.506 \\
\hline \multicolumn{8}{|c|}{ Diabetes and hyperglycemia } \\
\hline Crude OR (95\% Cl) & 1.00 & $1.33(1.10-1.60)$ & 0.003 & $1.30(0.98-1.74)$ & 0.073 & $1.34(1.06-1.70)$ & 0.014 \\
\hline Adjusted OR (95\% Cl) & 1.00 & $1.23(1.02-1.49)$ & 0.034 & $1.19(0.89-1.60)$ & 0.245 & $1.26(0.99-1.60)$ & 0.06 \\
\hline \multicolumn{8}{|l|}{ Dyslipidemia } \\
\hline Crude OR (95\% Cl) & 1.00 & $0.93(0.79-1.09)$ & 0.343 & $0.92(0.72-1.18)$ & 0.505 & $0.93(0.76-1.14)$ & 0.478 \\
\hline Adjusted OR (95\% Cl) & 1.00 & $0.95(0.81-1.13)$ & 0.576 & $0.98(0.76-1.26)$ & 0.862 & $0.94(0.76-1.16)$ & 0.551 \\
\hline \multicolumn{8}{|l|}{ MetS (JIS) } \\
\hline Crude OR (95\% Cl) & 1.00 & $1.21(0.99-1.49)$ & 0.065 & $1.02(0.74-1.43)$ & 0.889 & $1.34(1.05-1.73)$ & 0.021 \\
\hline Adjusted $^{*}$ OR (95\% Cl) & 1.00 & $1.21(0.98-1.49)$ & 0.075 & $1.05(0.75-1.46)$ & 0.797 & $1.32(1.02-1.69)$ & 0.034 \\
\hline \multicolumn{8}{|l|}{ MetS (JCCMS) } \\
\hline Crude OR (95\% CI) & 1.00 & $1.11(0.90-1.38)$ & 0.333 & $1.14(0.82-1.58)$ & 0.428 & $1.09(0.83-1.43)$ & 0.524 \\
\hline Adjusted $^{*} \mathrm{OR}(95 \% \mathrm{Cl}$ & 1.00 & $1.05(0.85-1.31)$ & 0.648 & $1.08(0.77-1.50)$ & 0.665 & $1.04(0.79-1.36)$ & 0.797 \\
\hline \multicolumn{8}{|l|}{ Ischemic heart disease } \\
\hline Crude OR (95\% Cl) & 1.00 & $1.12(0.75-1.89)$ & 0.464 & $1.00(0.46-2.15)$ & 0.996 & $1.31(0.75-2.29)$ & 0.336 \\
\hline Adjusted OR (95\% Cl) & 1.00 & $0.86(0.53-1.38)$ & 0.524 & $0.65(0.30-1.41)$ & 0.27 & $1.02(0.58-1.81)$ & 0.937 \\
\hline Women $(n-6,044)$ & $n=5,775$ & $n=269$ & & $n=212$ & & $n=57$ & \\
\hline \multicolumn{8}{|l|}{ Lung cancer } \\
\hline Crude OR (95\% CI) & 1.00 & $4.33(1.25-15.05)$ & 0.02 & $3.66(0.83-16.10)$ & 0.086 & $6.86(0.89-52.80)$ & 0.065 \\
\hline Adjusted OR (95\% Cl) & 1.00 & $3.42(0.97-12.11)$ & 0.057 & $2.82(0.63-12.64)$ & 0.176 & $5.95(0.75-47.32)$ & 0.09 \\
\hline \multicolumn{8}{|l|}{ Hypertension } \\
\hline Crude OR (95\% CI) & 1.00 & $1.71(1.34-2.19)$ & $<0.001$ & $1.74(1.32-2.29)$ & $<0.001$ & $1.61(0.95-2.73)$ & 0.08 \\
\hline Adjusted OR (95\% Cl) & 1.00 & $1.63(1.26-2.10)$ & $<0.001$ & $1.59(1.20-2.11)$ & 0.001 & $1.79(1.04-3.10)$ & 0.037 \\
\hline \multicolumn{8}{|l|}{ Diabetes and hyperglycemia } \\
\hline Crude OR (95\% Cl) & 1.00 & $1.63(1.20-2.23)$ & 0.002 & $1.74(1.24-2.45)$ & 0.001 & $1.25(0.61-2.56)$ & 0.54 \\
\hline Adjusted OR (95\% Cl) & 1.00 & $1.61(1.18-2.20)$ & 0.003 & $1.68(1.19-2.37)$ & 0.003 & $1.34(0.65-2.75)$ & 0.43 \\
\hline \multicolumn{8}{|l|}{ Dyslipidemia } \\
\hline Crude OR (95\% Cl) & 1.00 & $0.97(0.75-1.24)$ & 0.779 & $1.09(0.83-1.44)$ & 0.522 & $0.58(0.33-1.78)$ & 0.70 \\
\hline Adjusted OR (95\% Cl) & 1.00 & $0.90(0.70-1.16)$ & 0.418 & $1.00(0.75-1.32)$ & 0.982 & $0.89(0.43-1.82)$ & 0.74 \\
\hline \multicolumn{8}{|l|}{ MetS (JIS) } \\
\hline Crude OR (95\% CI) & 1.00 & $1.33(0.99-1.79)$ & 0.057 & $1.47(1.07-2.03)$ & 0.019 & $0.87(0.43-1.78)$ & 0.70 \\
\hline Adjusted $^{*}$ OR $(95 \% \mathrm{Cl})$ & 1.00 & $1.31(0.97-1.76)$ & 0.075 & $1.43(1.04-1.98)$ & 0.03 & $0.89(0.43-1.82)$ & 0.74 \\
\hline \multicolumn{8}{|l|}{ MetS (JCCMS) } \\
\hline Crude OR (95\% Cl) & 1.00 & $1.76(1.04-2.98)$ & 0.034 & $1.97(1.13-3.45)$ & 0.018 & $1.01(0.25-4.19)$ & 0.99 \\
\hline Adjusted $^{*} \mathrm{OR}(95 \% \mathrm{Cl})$ & 1.00 & $1.64(0.97-2.78)$ & 0.067 & $1.83(1.04-3.21)$ & 0.036 & $0.94(0.23-3.93)$ & 0.94 \\
\hline
\end{tabular}


The OR having diabetes and hyperglycemia compared with normal lung function was 1.23 for men and 1.61 for women in total AL, and 1.68 in mild AL for women. The pathophysiological link between COPD and diabetes is not entirely understood, although thought to involve systemic inflammation with central roles for IL-6 and TNF- $\alpha$ [23]. We found that the prevalence of MetS was higher when using JIS criteria than when using JCCMS criteria, especially in women, which were consistent with the study by $\mathrm{Hu} \mathrm{H}$. et al. [24]. $\mathrm{Hu} \mathrm{H}$ et al. demonstrated that the JIS criteria can detect more people who later develop diabetes mellitus than does the JCCMS criteria [24]. In men, MetS (JIS) (OR, 1.32; 95\% CI, 1.02-1.69) were significantly associated with moderate-to-very severe AL, after adjusting for sex, age, and smoking status. However, we found that MetS (JCCMS) was not significantly associated with moderate-to-very severe AL after adjusting for sex, age, and smoking status. In women, MetS (JIS) (OR, 1.68; 95\% CI, 1.19-2.37) and MetS (JCCMS) (OR, 1.83; 95\% CI, 1.04-3.21) were significantly associated with mild AL, after adjusting for sex, age, and smoking status. Previous studies have reported that diabetes and Mets are more frequent in COPD patients who are at the earlier stages of COPD [25-27]. The reason of the gender-difference is not clear. Further studies are needed to better understand the genderdifference. Our findings in men are consistent with our previous study [11]. These criteria differ in several aspects, including the cut-off points of waist circumference (WC), handling of the WC component (prerequisite or optional for the diagnosis of MetS), and the criteria of hyperglycemia and dyslipidemia [24]. These differences have led to confusion regarding the choice of the criteria to diagnose MetS [24]. Hu H. et al. very recently demonstrated that waist circumference cut-offs of $85 \mathrm{~cm}$ for men and $80 \mathrm{~cm}$ for women are appropriate in the Japanese population [24]. Additional research is needed to clarify this aspect of criteria.

Dyslipidemia is one of several parameters employed to diagnose metabolic syndrome [16, 17]. However, most studies have not demonstrated significant differences in the prevalence of dyslipidemia between COPD patients and control subjects $[23,28]$. Our findings are consistent with these previous studies.

Compared with the previous study by Smith et al., our study demonstrated a low ratio of ischemic heart disease [29]. According to the document of Global Initiative for Chronic Obstructive Lung Disease (GOLD), cardiovascular disease is a major comorbidity in COPD and probably both the most frequent and most important $[1,2]$. However, we found that ischemic heart disease is less prevalent in this study. In addition, ischemic heart disease was not significantly associated with AL after adjusting for sex, age, BMI, and smoking status in the present study. There are conflicting results regarding the association between COPD severity and the risk of cardiovascular comorbidity [25]. A review by Takahashi S et al. [25] demonstrated that the comorbidity spectrum of Japanese COPD patients seems to differ from that of Westerners. For example, they reported that cardiovascular disease is less prevalent Japanese COPD patients. The fact that the prevalence of cardiovascular comorbidities in Japanese COPD patients differs from that in Western patients may arise from ethnic or genetic differences, or from environmental differences including lifestyle and socioeconomic factors [25].

Studies have shown that osteoporosis, anxiety and depression are major comorbidities in COPD [1, 2, 29]. In this study, we observed a low ratio of osteoporosis, anxiety and depression. Further research is needed to elucidate the relationship between AL and these comorbidities.

COPD is characterized by persistent systemic inflammation $[1,6]$. Previous research found that the group of patients with severe COPD had significantly higher circulating leukocyte [6]. Our results are in line with this study. Systemic inflammation has been widely reported to be a key link between COPD and some comorbidities [23]. The source of systemic inflammation in COPD may be the results of a spill-over of airway and lung parenchymal processes [23]. While the causal relationship between COPD and comorbidities is not entirely clear, inactivity and systemic inflammation have been suggested as part of the mechanism for the comorbidities associated with COPD and may relate to the natural course of the disease [30, 31].

The strength of this study is estimating the prevalence of $\mathrm{AL}$ and comorbidities among subjects undergoing medical checkup. In this study, the prevalence of diagnosed COPD/emphysema among subjects with AL was only $6.6 \%$ in mild AL and $1.6 \%$ in moderate-to-very severe AL. Remaining had not been diagnosed with any respiratory diseases, suggesting a high degree of underdiagnosis of COPD. Conclusively, earlier diagnosis and intervention of COPD and its comorbidities could improve the prognosis of COPD for individual patients and reduce the disease burden of COPD on the society.

There are several limitations associated with the present study. First, we did not employ reversibility testing, since our Institutional Review Board considered it unacceptable in the absence of a high suspicion of disease. For this reason, the subjects with AL may have included subjects with a post-bronchodilator $\mathrm{FEV}_{1} / \mathrm{FVC}$ ratio greater than $70 \%$. Our study excluded any subjects who had ever received a diagnosis of asthma or other respiratory diseases except for lung cancer. Therefore, these individuals could possibly have COPD, and they may have even had asthma; thus, we expressed "AL" instead of COPD. This limitation has also been reported in the previous studies [8, 9]. A modified GOLD definition that omits bronchodilation has 
become widely adopted by population-based epidemiological studies [32]. Second, the presence of lung cancer, ischemic heart disease, osteoporosis, and depression and mental disease was confirmed by the interview by a trained public health nurse and a physician. The methodology used to report the presence of a comorbidity that is not completely objective because it was not based on confirmatory tests for each disease.

Third, because of the cross-sectional design, we cannot rule out the possibility that reverse causation may explain our results. Further larger-scale prospective studies are needed to further confirm our findings. Fourth, the present study was a single-center study performed with subjects who underwent a medical health checkup. This may limit applicability across different centers.

Despite these limitations, we consider the present study to be worthwhile because it is the first to reveal the relationship between AL severity and various comorbidities in comprehensive health examination, as far as the authors know.

\section{Conclusions}

In conclusion, a significant relationship was found between $\mathrm{AL}$ and the presence of comorbid lung cancer in men, hypertension in women, diabetes and hyperglycemia, and MetS in men and women. Further research investigating gender-based difference of comorbidity is needed. Similarly, further research is required to fully understand the relationships and underlying mechanisms between airflow limitation and the comorbidities. Our findings could have implications in the management of subjects with AL on medical health checkups. Efforts aimed at the earlier detection of AL and the identification of comorbidities may become integral for the reduction of the disease burden of COPD on the society. Knowledge of comorbidities associated with AL should be widely publicized to raise the awareness of COPD.

\section{Acknowledgement}

The authors would like to thank the technicians at the Japanese Red Cross Kumamoto Health Care Center for their excellent technical assistance.

\section{Authors' contributions}

All authors read and approved the final manuscript.

\section{Competing interests}

The authors declare that they have no competing interests.

\section{Publisher's Note}

Springer Nature remains neutral with regard to jurisdictional claims in published maps and institutional affiliations.

\section{Author details}

'Department of Public Health, Faculty of Life Sciences, Kumamoto University, 1-1-1 Honjou, Chuo-ku, Kumamoto 860-8556, Japan. ${ }^{2}$ Department of Biomedical Laboratory Sciences, Faculty of Life Sciences, Kumamoto University, 4-24-1 Kuhonji, Chuo-ku, Kumamoto 862-0976, Japan. ${ }^{3}$ Japanese Red Cross Kumamoto Health Care Center, 2-1-1 Nagamineminami, Higashi-ku, Kumamoto 861-8528, Japan.
Received: 23 August 2016 Accepted: 4 March 2017

Published online: 20 March 2017

\section{References}

1. Global Initiative for Chronic Obstructive Lung Disease. Global Strategy for the diagnosis, management, and prevention of chronic obstructive pulmonary disease, Updated 2015. http://goldcopd.org/. Accessed 8 Aug 2016.

2. Vestbo J, Hurd SS, Agusti AG, Jones PW, Vogelmeier C, Anzueto A, et al. Global strategy for the diagnosis, management, and prevention of chronic obstructive pulmonary disease: GOLD executive summary. Am J Respir Crit Care Med. 2013;187:347-65.

3. World Health Organization (WHO). The Top 10 Causes of Death Fact Sheet No 310. 2014. Available from: http://www.who.int/mediacentre/factsheets/ fs310/en/. Accessed 28 May 2015.

4. Divo M, Cote C, de Torres JP, Casanova C, Martin JM, Pinto-Plata V, BODE Collaborative Group, et al. Comorbidities and risk of mortality in patients with chronic obstructive pulmonary disease. Am J Respir Crit Care Med. 2012;186:155-61.

5. Mannino DM, Thorn D, Swensen A, Holguin F. Prevalence and outcomes of diabetes, hypertension and cardiovascular disease in COPD. Eur Respir J. 2008:32:962-9.

6. Sin DD, Anthonisen NR, Soriano JB, Agusti AG. Mortality in COPD: Role of comorbidities. Eur Respir J. 2006;28:1245-57.

7. Gershon AS, Mecredy GC, Guan J, Victor JC, Goldstein R, To T. Quantifying comorbidity in individuals with COPD: a population study. Eur Respir J. 2015;45:14-7.

8. Oda M, Omori H, Onoue A, Cui X, Lu X, Yada H, et al. Association between airflow limitation severity and arterial stiffness as determined by the brachial-ankle pulse wave velocity: A cross-sectional study. Intern Med. 2015 54(20):2569-75

9. Onoue A, Omori H, Katoh T, Kubota K, Nonami Y, Ogata Y, et al. Relationship of airflow limitation severity with work productivity reduction and sick leave in a Japanese working population. Int J Chron Obstruct Pulmon Dis. 2016;11:567-75.

10. Omori H, Tsuji M, Sata K, lyonaga C, Narimatsu A, Mihara S, et al. Correlation of $\mathrm{C}$-reactive protein with disease severity in $\mathrm{CT}$ diagnosed emphysema. Respirology. 2009;14:551-8.

11. Funakoshi Y, Omori H, Mihara S, Marubayashi T, Katoh T. Association between Airflow Obstruction and the Metabolic Syndrome or Its Components in Japanese Men. Intern Med. 2010:49(19):2093-9.

12. Omori H, Nagano M, Funakoshi Y, Onoue A, Mihara S, Marubayashi T, et al. Twelve-year cumulative incidence of airflow obstruction among Japanese males. Intern Med. 2011;50(15):1537-44.

13. Funakoshi Y, Omori H, Mihara S, Onoue A, Ogata Y, Aizawa H, et al. C-reactive protein levels, airflow obstruction, and chronic kidney disease. Environ Health Prev Med. 2012;17(1):18-26.

14. Miller MR, Hankinson J, Brusasco V, Burgos F, Casaburi R, Coates A, et al. ATS/ERS Task Force. Standardisation of spirometry. Eur Respir J. 2005;26:319-38.

15. Japanese Respiratory Society. Reference values for spirometry in Japanese adult [Internet]. Available from: http://www.jrs.or.jp/modules/guidelines/ index.php?content_id=12. cited 24 Apr 2016. (in Japanese).

16. Alberti KGMM, Eckel RH, Grundy SM, Zimmet PZ, Cleeman JI, Donato KA, et al. Harmonizing the metabolic syndrome: a joint interim statement of the International Diabetes Federation Task Force on Epidemiology and Prevention; National Heart, Lung, and Blood Institute; American Heart Association; World Heart Federation; International Athrosclerosis Society; and International Association for the Study of Obesity. Circulation. 2009;120:1640-5.

17. Committee to Evaluate Diagnostic Standards for Metabolic Syndrome Definition and diagnostic criteria for metabolic syndrome. Nippon Naika Gakkai Zasshi. 2005;94:794-809. (in Japanese)

18. Mannino DM, Aguayo SM, Petty TL, Redd SC. Low lung function and incident lung cancer in the United States: data from the first National Health and Nutrition Examination Survey follow-up. Arch Intern Med. 2003;163(12):1475-80.

19. de Torres JP, Marin JM, Casanova C, Cote C, Carrizo S, Cordoba-Lanus E, et al. Lung cancer in patients with chronic obstructive pulmonary disease: incidence and predicting factors. Am J Respir Crit Care Med. 2011;184:913-9.

20. Kiri VA, Soriano J, Visick G, Fabbri L. Recent trends in lung cancer and its association with COPD: an analysis using the UK GP Research Database. Prim Care Respir J. 2010;19(1):57-61. 
21. Rabe KF, Wedzicha JA, Wouters EFM, editors. COPD and comorbidity, European Respiratory Monograph. 2013. p. 59.

22. Loganathan RS, Stover DE, Shi W, Venkatraman E. Prevalence of COPD in women compared to men around the time of diagnosis of primary lung cancer. Chest. 2006;129:1305-12.

23. Patel ARC, Hurst JR. Extrapulmonary comorbidities in chronic obstructive pulmonary disease: state of the art. Expert Rev Respir Med. 2011;5(5):647-62.

24. Hu H, Kurotani K, Sasaki N, Murakami T, Shimizu C, Shimizu M, et al. Optimal waist circumference cut-off points and ability of different metabolic syndrome criteria for predicting diabetes in Japanese men and women: Japan Epidemiology Collaboration on Occupational Health Study. BMC Public Health. 2016;16:220-9.

25. Takahashi S, Betsuyaku T. The chronic obstructive pulmonary disease comorbidity spectrum in Japan differs from that in western countries. Respir Investig. 2015:53:259-70

26. Diez-Manglano J, Barquero-Romero J, Almagro P, Cabrera FJ, Lopez Garcia F, Montero L, Working Group on COPD; Spanish Society of Internal Medicine, et al. COPD patients with and without metabolic syndrome: clinical and functional differences. Intern Emerg Med. 2014;9:419-25.

27. Watz H, Waschki B, Kirsten A, Muller KC, Kretschmar G, Meyer T, et al. The metabolic syndrome in patients with chronic bronchitis and COPD. Frequency and associated consequences for systemic inflammation and physical inactivity. Chest. 2009;136:1039-46.

28. Basili S, Ferroni P, Vieri M, Cardelli P, Ceci F, Paradiso M, et al. Lipoprotein(a) serum levels in patients affected by chronic obstructive pulmonary disease. Atherosclerosis. 1999;147:249-52.

29. Smith MC, Wrobel JP. Epidemiology and clinical impact of major comorbidities in patient with COPD. Int J Chron Obstruct Pulmon Dis. 2014;9:871-88.

30. Fabbri LM, Luppi F, Beghe B, Rabe KF. Complex chronic comorbidities of COPD. Eur Respir J. 2008;31:204-12.

31. Price D, Freeman D, Cleland J, Kaplan A, Cerasoli F. Earlier diagnosis and earlier treatment of COPD in primary care. Prim Care Respir J. 2011;20:15-22.

32. Mannino DM, Buist AS. Global burden of COPD: risk factors, prevalence, and future trends. Lancet. 2007:370:765-73.

\section{Submit your next manuscript to BioMed Central and we will help you at every step:}

- We accept pre-submission inquiries

- Our selector tool helps you to find the most relevant journal

- We provide round the clock customer support

- Convenient online submission

- Thorough peer review

- Inclusion in PubMed and all major indexing services

- Maximum visibility for your research

Submit your manuscript at www.biomedcentral.com/submit
Biomed Central 